SCJR 13, no. 1 (2018): 1-3

\title{
Gerald R. McDermott Israel Matters: Why Christians Must Think Differently about the People and the Land
}

\author{
(Grand Rapids, MI: Brazos Press, 2017), paperback, xvii + 158 pp.
}

\author{
JAY MOSES \\ pastorjaym@sbcglobal.net \\ Hope Presbyterian Church, Wheaton, IL 60189
}

This is one of the latest contributions to the vibrant and wide-spread study of Christian Zionism. It could be said in our day that of the writing of books regarding Christian Zionism there is no end. This is of course a controversial topic. Some modern Christians' religious support of Jewish sovereignty within the ancient Land of Israel is dismissed from the left as dispensationalist fanaticism, while criticism of Israel by those on the religious left has been labeled by those on the right as antisemitism redivivus. What Gerald McDermott seeks to do in his new book is to find a via media for what he describes as a "New Christian Zionism." What makes this Christian Zionism "new" will be discussed below. (This monograph was published shortly after The New Christian Zionism: Fresh Perspectives on Israel and the Land [2016], a collection of essays McDermott edited.)

McDermott seeks to ground his theological project in Christian orthodoxy (Jonathan Edwards is a special place of ressourcement). He engages with modern religious trends, such as Western religious pluralism, and draws on his experience in religious dialogue (he has written several books on dialogue with the Mormons). In his earlier dialogical works, he sought to be a mediator between sharply divided sides. In the same way, Israel Matters reflects this desire to find fresh approaches to stale theological contestations between partners long estranged.

Although members of other religious traditions such as Mainline Protestants, Roman Catholics, and Jews are welcome to listen in, his "new" form of Christian Zionism is addressed to those with a conservative / evangelical theological background, similar to his own. This is apparent at the start. In his introduction he quotes a "young Christian leader": "I was raised in a conservative church and naively supported whatever Israel did. We were led to believe that God had given the land of Israel to his people, the Jews, and their fight for their land in 1948 was a religious act by a religious people looking to their God" (p. ix). However, she now questions this claim, on both theological and ethical grounds. McDermott 
recognizes the cogency of various critiques of Israel, and also recognizes a lack of evangelical support for Israel on traditional dispensationalist grounds. Because, as his title says, Israel does matter, he wants to present a new evangelical perspective on these topics.

As suggested by his questioner, he seeks to approach such a study without a faith-based naiveté, recognizing that Israel, especially within its complex geopolitical context, begs for greater seriousness, ethical and otherwise. In short, one might say he wrestles with the question of whether God takes sides in the many geo-political conflicts in our world, and, more precisely, does God take a side in the Israeli / Palestinian conflict? Is the Israeli government's occupation of the West Bank religiously significant, he ponders, and if so, what ethical issues get raised? This note of concern for Palestinians reflects somewhat of an evolution in evangelical ethics and thought, and McDermott embodies it in his troubled conscience and musings.

As in some other current works from evangelicals with concerns for JewishChristian relations, he rejects replacement theology. McDermott does a good job of narrating the historical development of this theological claim in section headings with memorable titles ("Irenaeus-Unnecessary Israel," "Origen-Spiritualizing Israel," "Luther / Calvin-Repudiating Israel" [pp. 7-10]). He also narrates later manifestations of this idea, studying the views of English Deists and Friedrich Schleiermacher. He does not, however, engage the views of Palestinian Christian theologians (such as Naim Ateek and Mitri Raheb) or contemporary non-Zionist evangelicals (such as Stephen Sizer and Gary Burge), which could easily have been added. McDermott's review of traditional Christian anti-Jewish theology leads to a final historical destination: the Shoah.

McDermott's own views begin to emerge as he reviews earlier theological views with the potential to contribute to a new form of Christian Zionism, one built on an ethical foundation and supportive of a hopeful future between Christians and Jews. He rejects the dominant evangelical dispensational theologies of John Nelson Darby and its fundamentalist offspring. Instead, he seeks to dig within the heritage of English Puritan theologians (e.g., Thomas Draxe, Thomas Brightman, John Cotton, and Increase Mather) whose eschatological views preserve a special role for Israel. He also draws upon the works of Karl Barth (who is increasingly popular among evangelicals) and some lesser known twentiethcentury thinkers, such as Russian orthodox theologian Lev Gillet and the Catholic Mother Basilea Schlink. (He might have considered other restorationist, nondispensationalist theologians such as Joachim of Fiore, Jonathan Edwards, and Wilhelmus à Brakel.) He eschews the dispensationalists' predictive prophecy and separation of Jews and Gentiles on different eschatological tracks. The Jews' return to the land is a fulfillment of biblical prophecy found in both testaments, though the state of Israel is not exempt from ethical requirements. Much about Israel remains a mystery, he admits, but McDermott supports and advocates for its central role in Scriptural and modern day history. Although his theology of the Jewish people is similar to other recent approaches, his recovery of the theological significance of the physical land leads him into interesting proposals 
regarding the existence, evolution, and struggles of the state. Unlike the view of Israel in dispensational theologies, where it is seen solely in terms of Christian salvation, McDermott ponders a more mature reflection of God's revelation and consequences for all involved.

Perhaps wisely, McDermott largely refrains from applying too directly insights from theology to a convoluted and war-torn geo-political reality. However, his book feels somewhat disconnected from the contemporary context. Surely, it is a daunting challenge to move from theological insights to concrete circumstances. As in all such attempts, dangers loom of presenting a complex situation oversimplistically, and of forcing a priori theological commitments onto a gritty reality. And yet, for faithful and also politically engaged communities whom McDermott addresses, such a risk might be taken for the sake of religious growth, and to show the relevance of theologically informed worldviews. (This is especially relevant if God is seen not as absent from such places but rather may be discerned, even with trepidation and shrouded mystery.)

Also, it is significant to recognize that McDermott, an evangelical Christian, engages with leading thinkers in Jewish / Christian dialogue, an endeavor that has primarily involved Mainline Protestant and Roman Catholic Christians (as well as Jews). He engages the work of Mark Nanos, Scott Bayder-Saye, Daniel Boyarin, John Gager, Krister Stendahl, Irving Greenberg, and Markus Barth. We learn that McDermott, and increasingly other evangelical Christians, have not been aloof, but rather listening quite intently to these theological conversations. The emergence of such "conversations" between different branches of the Christian world, whether literal or even in scholarly writing, meets great needs of our time, such as a broad and inclusive search for the humane, for a cross-fertilization of ideas about our ethical mandates. To paraphrase McDermott, Israel does matter, and such dialogue offers promise for a fuller ecumenicism. May this conversation continue. 